\title{
DEMAM TIFOID : MANIFESTASI KLINIS, PILIHAN TERAPI DAN PANDANGAN DALAM ISLAM
}

\author{
Yelvi Levani $^{1}$, Aldo Dwi Prastya ${ }^{2}$ \\ 1,2 Universitas Muhammadiyah Surabaya \\ e-mail : yelvilevani@fk-um.surabaya.ac.id
}

\begin{abstract}
Typhoid fever is an acute infectious disease of the digestive system caused by the bacteria Salmonella typhi or Salmonella paratyphi. Typhoid fever is a global infectious disease in which an estimated 26.9 million cases of typhoid fever are found worldwide. Typhoid fever is especially common in developing countries because it is associated with poor sanitation. Clinical manifestations of typhoid fever that arise can vary from mild to severe symptoms. Symptoms of typhoid fever that are often found are fever, malaise, abdominal pain and constipation. Culture examination is a gold standard examination in establishing the diagnosis of typhoid fever. But this examination is rarely done. The first-line treatment option for typhoid fever is chloramphenicol. However, as the bacterial resistance to chloramphenicol increases, the main therapeutic choice for typhoid fever is the fluoroquinolone antibiotic.
\end{abstract}

Keywords : typhoid fever, Salmonella typhi, therapy

\begin{abstract}
Abstrak
Demam tifoid merupakan penyakit infeksi akut sistem pencernaan yang disebabkan oleh bakteri Salmonella typhi atau Salmonella paratyphi. Demam tifoid merupakan penyakit infeksi global dimana diperkirakan 26,9 juta kasus demam tifoid ditemukan diseluruh dunia. Demam tifoid banyak terjadi terutama di negara-negara berkembang karena berkaitan dengan sanitasi yang kurang baik. Manifestasi klinis demam tifoid yang timbul dapat bervariasi dari gejala ringan hingga berat. Gejala demam tifoid yang sering ditemukan adalah demam, malaise, nyeri perut dan konstipasi. Pemeriksaan kultur merupakan pemeriksaan gold standard dalam menegakkan diagnosis demam tifoid. Namun pemeriksaan ini jarang dilakukan. Pilihan terapi lini pertama dari demam tifoid adalah kloramfenikol. Namun seiring dengan meningkatknya resistensi bakteri terhadap kloramfenikol, maka pilihan terapi utama dari demam tifoid adalah antibiotik golongan fluoroquinolon.
\end{abstract}

Kata kunci : Demam Tifoid, Salmonella Typhi, Terapi

\section{PENDAHULUAN}

Demam tifoid merupakan penyakit infeksi akut sistem pencernaan yang disebabkan oleh bakteri Salmonella typhi atau Salmonella paratyphi. Demam tifoid merupakan penyakit infeksi global, terutama di negara-negara berkembang. Demam tifoid ditularkan melalui makanan atau minuman yang terkontaminasi oleh bakteri Salmonella typhi, selain itu penyakit ini dapat ditularkan melalui kontak langsung dengan feses, urin atau sekret penderita demam tifoid. Dengan kata lain hygiene sanitasi adalah faktor utama penularannya.
Manifestasi klinis demam tifoid yang timbul dapat bervariasi dari gejala ringan hingga berat. Gejala klinis yang klasik dari demam tifoid diantaranya adalah demam, malaise, nyeri perut dan konstipasi. Pemeriksaan kultur merupakan pemeriksaan gold standard untuk menegakkan diagnosis demam tifoid. Namun harganya yang mahal dan waktu pemeriksaan yang lama membuat pemeriksaan kultur ini jarang dilakukan. 


\section{TINJAUAN PUSTAKA}

\section{Epidemiologi}

Data global pada tahun 2010, diperkirakan 26,9 juta kasus demam tifoid diseluruh dunia (4). Demam tifoid banyak dijumpai di negara-negara berkembang dan pada daerah tropis dengan angka kejadian sekitar 21 juta dan berakhir kematian sekitar 700 kasus. Hal ini menyebabkan demam tifoid masih menjadi masalah serius. Berdasarkan studi epidemiologi yang dilakukan di lima negara Asia, insidensi kasus demam tifoid di Indonesia sekitar 81,7 kasus per 100.000 penduduk per tahun. Angka tersebut masih dibawah Pakistan 451,7 kasus per 100.000 penduduk per tahun dan India 493,5 kasus per 100.000 per tahun. Prevalensi angka kejadian demam tifoid di Indonesia menurut data Kementerian Kesehatan RI menyebutkan sekitar 350810 per 100.000 penduduk. Itu artinya tiap tahun ada sebesar 600.000-1.500.000 kasus demam tifoid.

\section{Patofisiologi}

Penyebab demam tifoid adalah bakteri Salmonella typhi atau Salmonella paratyphi. Bakteri Salmonella typhi merupakan bakteri basil gram negatif ananerob fakultatif. Bakteri Salmonella akan masuk kedalam tubuh melalui oral bersama dengan makanan atau minuman yang terkontaminasi. Sebagian bakteri akan dimusnahkan dalam lambung oleh asam lambung. Sebagian bakteri Salmonella yang lolos akan segera menuju ke usus halus tepatnya di ileum dan jejunum untuk berkembang biak. Bila sistem imun humoral mukosa (IgA) tidak lagi baik dalam merespon, maka bakteri akan menginvasi kedalam sel epitel usus halus (terutama sel $\mathrm{M}$ ) dan ke lamina propia. Di lamina propia bakteri akan difagositosis oleh makrofag. Bakteri yang lolos dapat berkembang biak didalam makrofag dan masuk ke sirkulasi darah (bakterimia I). Bakterimia I dianggap sebagai masa inkubasi yang dapat terjadi selama 7-14 hari Bakteri Salmonella juga dapat menginvasi bagian usus yang bernama plak payer. Setelah menginvasi plak payer, bakteri dapat melakukan translokasi ke dalam folikel limfoid intestin dan aliran limfe mesenterika dan beberapa bakteri melewati sistem retikuloendotelial di hati dan limpa. Pada fase ini bakteri juga melewati organ hati dan limpa. Di hati dan limpa, bakteri meninggalkan makrofag yang selanjutnya berkembang biak di sinusoid hati. Setelah dari hati, bakteri akan masuk ke sirkulasi darah untuk kedua kalinya (bakterimia II).

Saat bakteremia II, makrofag mengalami hiperaktivasi dan saat makrofag memfagositosis bakteri, maka terjadi pelepasan mediator inflamasi salah satunya adalah sitokin. Pelepasan sitokin ini yang menyebabkan munculnya demam, malaise, myalgia, sakit kepala, dan gejala toksemia. Plak payer dapat mengalami hyperplasia pada minggu pertama dan dapat terus berlanjut hingga terjadi nekrosis di minggu kedua. Lama kelamaan dapat timbul ulserasi yang pada akhirnya dapat terbentuk ulkus diminggu ketiga. Terbentuknya ulkus ini dapat menyebabkan perdarahan dan perforasi. Hal ini merupakan salah satu komplikasi yang cukup berbahaya dari demam tifoid.

\section{Gejala klinis}

Penegakan diagnosis sedini mungkin akan bermanfaat untuk pemberian terapi yang tepat dan atau mengurangi risiko komplikasi. Gejala klinis demam tifoid yang pasti dijumpai adalah demam. Gejala demam meningkat perlahan ketika menjelang sore hingga malam hari dan akan turun ketika siang hari. Demam akan semakin tinggi (39 - 40 derajat Celsius) dan menetap pada minggu kedua. Masa inkubasi demam tifoid sekitar 7 sampai 14 hari (dengan rentang 3 sampai 60 hari) (3). Gejala demam tifoid umumnya tidak spesifik, diantaranya adalah demam, sakit 
kepala, anoreksia, myalgia, athralgia, nausea, nyeri perut dan konstipasi. Pada anak-anak dan penderita HIV yang terkena demam tifoid, umumnya lebih banyak mengalami keluhan diare (8). Pada pemeriksaan fisik dapat ditemukan demam tinggi, bradikardi relatif, lidah kotor, hepatomegali, nyeri tekan abdomen, splenomegali atau rose spot (3). Rose spot merupakan kumpulan lesi makulopapular eritematus dengan diameter 2 sampai 4 mm yang sering ditemukan pada perut dan dada. Tanda rose spot ini terdapat pada 5 sampai 30\% kasus dan tidak terlihat pada pasien kulit gelap (3). Gejala klinis yang disebabkan oleh bakteri Salmonella paratyphi umumnya lebih ringan daripada gejala yang disebabkan oleh bakteri Salmonella typhi.

\section{Pemeriksaan laboratorium}

\section{a. Pemeriksaan darah tepi}

Pemeriksaan darah tepi seperti jumlah eritrosit, leukosit dan trombosit umumnya tidak spesifik untuk mendiagnosis demam tifoid. Leukopenia sering ditemukan pada kasus demam tifoid, tetapi jumlah leukosit jarang kurang dari 2.500/mm3. Kondisi leukopenia dapat menetap 1 sampai 2 minggu setelah infeksi. Pada kondisi tertentu, jumlah leukosit dapat ditemukan meningkat (20.000-25.000/mm3). Hal ini dapat berkaitan dengan adanya abses pyogenic atau adanya infeksi sekunder pada usus. Selain hitung jumlah leukosit yang tidak normal, anemia normokromik normositer dapat ditemukan beberapa minggu setelah infeksi demam tifoid. Kondisi ini dapat disebabkan oleh pengaruh sitokin dan mediator inflamasi sehingga menyebabkan depresi sumsum tulang belakang. Selain itu, kondisi ini juga dapat berkaitan dengan perdarahan dan perforasi usus. Adanya trombositopenia pada pasien demam tifoid menandakan adanya komplikasi penyakit koagulasi intravaskuler (disseminated intravascular coagulation).

\section{b. Pemeriksaan serologi widal}

Uji widal dilakukan untuk deteksi antibodi terhadap bakteri Salmonella typhi. Uji widal ini memiliki sensitivitas dan sensitivitas rendah. Pemeriksaan ini dilakukan dengan melihat aglutinasi dalam serum penderita aglunitin yang dideteksi yaitu aglutinin $\mathrm{O}$, aglutinin $\mathrm{H}$ dan aglutinin Vi. Namun interpretasinya hanya dari aglutinin $\mathrm{O}$ dan $\mathrm{H}$ saja. pemeriksaan widal sebaiknya mulai dilakukan pada minggu pertama demam. Hal ini dikarenakan aglutinin baru meningkat pada minggu pertama dan akan semakin tinggi hingga minggu keempat. Pembentukan aglutinin dimulai dari aglutinin $\mathrm{O}$ dan diikuti dengan aglutinin $\mathrm{H}$. Pada penderita demam tifoid yang telah bebas demam, aglutinin $\mathrm{O}$ akan tetap ditemukan hingga 4-6 bulan sedangkan aglutinin $\mathrm{H}$ 9-12 bulan. Oleh karena itu, uji widal tidak dapat dijadikan acuan kesembuhan pasien demam tifoid.

\section{c. Uji typhidot}

Uji typhidot dilakukan untuk mendeteksi antibodi IgM dan IgG yang terdapat pada protein membran bakteri Salmonella typhi. Uji ini dapat dilakukan dengan hasil positif 2-3 hari pasca terinfeksi dengan sensitivitas 98\%, spesifisitas sebesar 76,6\%. Uji ini hampir sama dengan uji tubex.

\section{d. Pemeriksaan kultur}

Pemeriksaan kultur merupakan pemeriksaan gold standard dalam menegakkan diagnosis demam tifoid. Pemeriksaan kultur memiliki tingkat spesifisitas $100 \%$. Pemeriksaan kultur Salmonella typhi dari darah dan feses pada minggu pertama infeksi memiliki tingkat sensitivitas sebesar $85-90 \%$ dan kemudian menurun sekitar $20-30 \%$ seiring berjalannya waktu. Selain dari darah dan feses, pemeriksaan kultur juga dapat dilakukan dengan menggunakan sampel urin dan cairan aspirasi sumsum tulang belakang. Pemeriksaan kultur dari sampel urin umumnya kurang sensitif $(25-30 \%)$. 
Sedangkan pemeriksaan kultur dari sampel cairan aspirasi sumsum tulang belakang memiliki sensitivitas $90 \%$ sampai pasien mendapatkan terapi antibiotik selama 5 hari. Namun, tindakan aspirasi sumsum tulang belakang dapat menyebakan nyeri, sehingga harus dipertimbangkan manfaat dan risikonya bila ingin melakukan pemeriksaan ini (11).

\section{Terapi farmakologi}

\section{a. Terapi antibiotika}

Di daerah endemik, 60 sampai $90 \%$ kasus demam tifoid dapat ditangani dengan pemberian antibiotik dan istirahat di rumah. Pada awalnya, antibiotik kloramfenikol merupakan pilihan terapi utama demam tifoid. Namun pada tahun 1990an, terjadi resistensi bakteri Salmonella typhi terhadap antibiotik kloramfenikol. Saat ini, antibiotik golongan fluoroquinolon dianggap merupakan pilihan utama dalam mengatasi demam tifoid. Pada sebuah studi, ditemukan bahwa antibiotik golongan fluoroquinolon memiliki lama waktu terapi yang relatif pendek $(3-7$ hari $)$ dan memiliki tingkat kesembuhan sebesar 96\%. Antibiotik golongan fluoroquinolon menunjukkan lebih cepat dan lebih efektif menurunkan jumlah bakteri Salmonella typhi di feses bila dibandingkan terapi lini pertama seperti kloramfenikol dan trimetoprim-sulfametoksazol. Selain antibiotika golongan fluoroquinolon, antibiotika golongan cefalosporin generasi ketiga (ceftriakson, cefiksim dan cefoperazon) dan azitromisin juga terbukti efektif dalam mengatasi demam tifoid. Pada sebuah studi ditemukan pemberian antibiotik ceftriakson dan cefiksim dapat menurunkan gejala demam dalam waktu 1 minggu pengobatan. Antibiotik kloramfenikol, amoksisilin dan trimetoprim sulfametoksazol masih bisa diberikan pada daerah yang tidak memiliki resistensi terhadap obat ini atau bila obat antibiotik golongan fluoroquinolon tidak dapat ditemukan.

Selain terapi antibiotik, asupan nutrisi dan cairan juga diperlukan untuk pasien demam tifoid. Pasien demam tifoid disarankan untuk mengkonsumsi diet lunak rendah serat. Asupan serat maksimal yang dianjurkan adalah 8 gram/ hari. Pasien disarankan untuk menghindari susu, daging berserat kasar, lemak terlalu manis, asam, bumbu tajam serta diberikan dalam porsi kecil. Selain itu pasien disarankan untuk tirah baring selama 7 hari setelah bebas demam. Untuk mengurangi risiko terjadinya penularan maupun relaps, maka pasien dan keluarganya disarankan untuk menjaga kebersihan .

Tabel 1. Terapi antibiotika untuk demam tifoid

\begin{tabular}{lll}
\hline Antibiotik & Dosis & Keterangan \\
\hline Ciprofloxacin (8) & $\begin{array}{l}\text { PO 5-7 hari } \\
\text { Dewasa: 1 gram/hari dalam 2 dosis } \\
\text { terbagi } \\
\text { Anak: 30mg/KgBB/hari dalam 2 dosis } \\
\text { terbagi }\end{array}$ & $\begin{array}{l}\text { Tidak direkomendasikan pada anak } \\
\text { dibawah 15 tahun akan tetapi resiko yang } \\
\text { mengancam jiwa dari tifoid melebihi } \\
\text { resiko efek samping }\end{array}$ \\
\hline \multirow{3}{*}{ Cefixime (8) } & $\begin{array}{l}\text { PO 7 hari } \\
\text { Anak (lebih dari usia 3 bulan) : } \\
\text { 20mg.kgBB/hari dalam 2 dosis terbagi }\end{array}$ & $\begin{array}{l}\text { Dapat menjadi alternatif ciprofloxacin } \\
\text { bagi anak dibawah 15 tahun }\end{array}$ \\
& $\begin{array}{l}\text { PO 14 hari } \\
\text { Dewasa: 3 gram/hari dalam 3 dosis } \\
\text { terbagi } \\
\text { Anak: 75-100mg/kgBB/hari terbagi } \\
\text { dalam 3 dosis }\end{array}$ & Jika tidak mengalami resistensi \\
\hline & $\begin{array}{l}\text { PO 10-14 hari (tergantung keparahan) } \\
\text { Anak: } \\
\text { 1-12 tahun: 100mg/kgBB/hari dalam 3 }\end{array}$ & Jika tidak mengalami resistensi \\
\hline
\end{tabular}




\begin{tabular}{lll}
\hline & $\begin{array}{l}\text { dosis terbagi } \\
>13 \text { tahun: } 3 \text { gram/hari dalam 3 dosis } \\
\text { terbagi }\end{array}$ & \\
\hline Tiamfenikol (9) & $\begin{array}{l}\text { PO 5-6 hari } \\
75 \mathrm{mg} / \mathrm{kgBB} / \mathrm{hari}\end{array}$ & $\begin{array}{l}\text { Efek hematologis pada pengguna } \\
\text { tiamfenikol lebih jarang dari pada } \\
\text { kloramfenikol }\end{array}$ \\
\hline Azitromisin (9) & PO 6 hari & $\begin{array}{l}\text { Efektif dan aman diberikan pada anak } \\
\text { dan dewasa yang mengalami demam } \\
\text { tifoid tanpa komplikasi }\end{array}$ \\
& 20mg/kgBB/hari & $\begin{array}{l}\text { Salmonella typhi dengan cepat } \\
\text { berkembang resisten terhadap kuinolon. } \\
\text { Pada kasus ini gunakan ceftriaxone }\end{array}$ \\
& $\begin{array}{l}\text { Infus (30 menit) } \\
\text { 10-14 hari (tergantung keparahan) } \\
\text { Dewasa: 2-4 gram sehari sekali } \\
\text { Anak: } 75 / \mathrm{kgBB} \text { sekali sehari }\end{array}$ & \\
\hline
\end{tabular}

Tabel 2: Antibiotika untuk demam tifoid pada ibu hamil dan menyusui

\begin{tabular}{|c|c|c|}
\hline Antibiotik & Dosis & Keterangan \\
\hline Amoksisilin (8) & $\begin{array}{l}\text { PO } 14 \text { hari } \\
\text { Dewasa: } 3 \text { gram/hari dalam dosis } 3 \\
\text { terbagi }\end{array}$ & Jika tidak mengalami resisten \\
\hline Ceftriaxone* (8) & $\begin{array}{l}\text { IM/IV ( } 3 \text { menit) } \\
\text { Infus ( } 30 \text { menit) } \\
\text { 10-14 hari (tergantung keparahan) } \\
\text { Dewasa: } 2-4 \text { gram sehari sekali }\end{array}$ & $\begin{array}{l}\text { Jika adanya resisten namun jika gagal } \\
\text { direkomendasikan ciprofloxacin (umumnya } \\
\text { tidak direkomendasikan untuk ibu hamil } \\
\text { dan menyusui) PO 5-7 hari } \\
\text { Dewasa: } 1 \text { gram/hari dalam } 2 \text { dosis terbagi } \\
\text { akan tetapi resiko yang mengancam jiwa } \\
\text { dari tifoid melebihi resiko efek samping }\end{array}$ \\
\hline
\end{tabular}

*pelarut ceftriaxone untuk IM menggunakan lidocaine (tidak boleh digunakan dengan rute IV: untuk pemberian IV menggunakan pelarut air injeksi

\section{Kedokteran Islam}

Sebagaimana penyebab utama terjadinya demam tifoid yakni mengenai hygine sanitasi adapun Allah berfirman tentang perintah menjaga kebersihan dan adanya anjuran terkait makan yang tidak berlebihan.

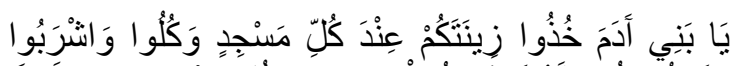

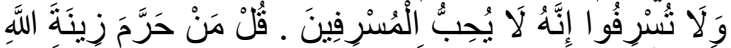

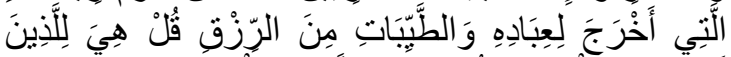

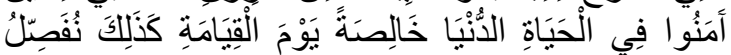

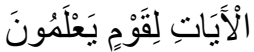

"Wahai anak Adam, pakailah pakaianmu yang indah (bersih dan rapi -pen) di setiap (memasuki) mesjid, makan dan minumlah, dan janganlah berlebih-lebihan. Sesungguhnya Allah tidak menyukai orang-orang yang berlebih-lebihan. Katakanlah, "Siapakah yang mengharamkan perhiasan dari Allah yang telah dikeluarkan-Nya untuk hambahamba-Nya dan (siapa pulakah yang mengharamkan) rizki yang baik?" Katakanlah, "Semuanya itu (disediakan) bagi orang-orang yang beriman dalam kehidupan dunia, khusus (untuk mereka saja) di hari kiamat." Demikianlah Kami menjelaskan ayat-ayat itu bagi orang-orang yang mengetahui." (12)

\section{KESIMPULAN}

Demam tifoid merupakan infeksi saluran pencernaan yang disebabkan oleh bakteri Salmonella typhi. Demam tifoid umumnya tidak memiliki gejala spesifik dan pemeriksaan kultur merupakan pemeriksaan gold standard. Demam tifoid berkaitan erat dengan sanitasi yang buruk. Pilihan antibiotik untuk demam tifoid adalah golongan dari fluoroquinolon. 


\section{DAFTAR PUSTAKA}

1. LUBY SP, FAIZAN MK, FISHERHOCH SP, SYED A, MINTZ ED, BHUTTA ZA, et al. Risk factors for typhoid fever in an endemic setting, Karachi, Pakistan. Epidemiol Infect [Internet]. 1998 Mar 1;120(2):129-38. Available from: https://www.cambridge.org/core/prod uct/identifier/S0950268897008558/ty pe/journal_article

2. Rahmasari V, Lestari K, Farmasi F, Padjadjaran U. Farmaka Farmaka. 16:184-95.

3. Parry CM, Hien TT, Dougan G, White NJ, Farrar JJ. Typhoid Fever. N Engl J Med [Internet]. 2002 Nov 28;347(22):1770-82. Available from: http://www.nejm.org/doi/abs/10.1056/ NEJMra020201

4. Buckle GC, Walker CLF, Black RE. Typhoid fever and paratyphoid fever: Systematic review to estimate global morbidity and mortality for 2010 . J Glob Health [Internet]. 2012 Jun;2(1):010401. Available from: http://www.ncbi.nlm.nih.gov/pubmed/ 23198130

5. Ochiai RL. a study of typhoid fever in five Asian countries: disease burden and implications for controls. Bull World Health Organ [Internet]. 2008 Apr 1;86(4):260-8. Available from: http://www.who.int/bulletin/volumes/ 86/4/06-039818.pdf

6. Cita YP. Bakteri salmonella typhi dan demam tifoid. (Vi):42-6.

7. Crump JA, Sjölund-Karlsson M, Gordon MA, Parry CM. Epidemiology, Clinical Presentation, Laboratory Diagnosis, Antimicrobial Resistance, and Antimicrobial Management of Invasive Salmonella Infections. Clin Microbiol Rev [Internet]. 2015 Oct 15;28(4):901-37. Available from: http://cmr.asm.org/lookup/doi/10.1128 /CMR.00002-15
8. Vinh H, Wain J, Vo TN, Cao NN, Mai TC, Bethell D, et al. Two or three days of ofloxacin treatment for uncomplicated multidrug-resistant typhoid fever in children. Antimicrob Agents Chemother [Internet]. 1996 Apr;40(4):958-61. Available from: http://www.ncbi.nlm.nih.gov/pubmed/ 8849259

9. Dobinson HC, Gibani MM, Jones C, Thomaides-Brears HB, Voysey M, Darton TC, et al. Evaluation of the Clinical and Microbiological Response to Salmonella Paratyphi A Infection in the First Paratyphoid Human Challenge Model. Clin Infect Dis [Internet]. 2017 Apr 15;64(8):1066-73. Available from: https://academic.oup.com/cid/articlelookup/doi/10.1093/cid/cix042

10. Sucipta Made A.A. Baku Emas Pemeriksaan Laboratorium Demam Tifoid pada Anak. J Skala Husada. 2015;12(1):22-6.

11. Wain J, Bay PVB, Vinh H, Duong NM, Diep TS, Walsh AL, et al. Quantitation of Bacteria in Bone Marrow from Patients with Typhoid Fever: Relationship between Counts and Clinical Features. J Clin Microbiol [Internet]. 2001 Apr 1;39(4):1571-6. Available from: http://jcm.asm.org/cgi/doi/10.1128/JC M.39.4.1571-1576.2001

12. Mirza SH, Beechmg NJ, Hart CA. Multi-drug resistant typhoid: a global problem. J Med Microbiol [Internet]. 1996 May 1;44(5):317-9. Available from:

https://www.microbiologyresearch.org /content/journal/jmm/10.1099/002226 15-44-5-317

13. Parry CM, Ho VA, Phuong LT, Bay PVB, Lanh MN, Tung LT, et al. Randomized controlled comparison of ofloxacin, azithromycin, and an ofloxacin-azithromycin combination for treatment of multidrug-resistant and nalidixic acid-resistant typhoid fever. Antimicrob Agents Chemother 
[Internet]. 2007 Mar;51(3):819-25.

Available from: http://www.ncbi.nlm.nih.gov/pubmed/ 17145784

14. Upadhyay R, Nadka MY, Muruganathan A, Tiwaskar M, Amarapurkar D, Banka NH, et al. API Recommendations for the Management of Typhoid Fever. J Assoc Physicians India [Internet]. 2015 Nov;63(11):77-96. Available from:

http://www.ncbi.nlm.nih.gov/pubmed/ 29900721 